\title{
МІЦНІСТЬ ДОТИЧНОГО ЗЧЕПЛЕННЯ \\ МІЖ СТАРИМ І НОВИМ БЕТОНАМИ У ЗБІРНО-МОНОЛІТНИХ КОНСТРУКЦІЯХ
}

\section{THE STRENGTH OF TANGENTIAL ADHESION BETWEEN OLD AND NEW CONCRETE IN PRECAST-MONOLITHIC STRUCTURES}

Дорофсєв В.С. д.Т.Н., проф., (Одеський національний морський університет), Пушкар Н.В., к.т.н, доц., (Одеська державна академія будівництва та архітектури, м. Одеса)

Dorofeev V.S., Doctor of Engineering, Professor, (Odessa National Maritime University), Pushkar N.V., Ph.D. in Engineering, Associate Professor, (Odessa State Academy of Civil Engineering and Architecture, Odessa)

Експериментально доведено вплив факторів складу старого і нового бетонів, а також поверхні старого бетону на міцність дотичного зчеплення між старим і новим бетонами у збірномонолітних конструкціях. Наведені запропоновані склади бетонів в залежності від досліджених факторів.

The article presents a research of the strength of the tangential adhesion between the old and the new concrete in prefabricated monolithic structures.

Most buildings and structures last time are built at composite concrete and reinforced concrete structures. It is known that the operational properties of precast-monolithic structures, such as stiffness, stability, crack resistance, the degree of impermeability at the joints, depend on the strength of contacts and the solidity of reinforced concrete joints. Therefore, during reconstruction, strengthening of structures, as well as in other cases, in designing, great attention is paid to the design of joints and their implementation.

The surface of the old concrete, with which it is necessary to ensure the adhesion of new concrete, is a cement stone with placeholders, pores and initial cracks. The adhesion of old concrete with new depends on the 
structure of old concrete and its properties. From the side of new concrete, adhesion depends on the cement paste, which has the properties of a binder.

In this article, using mathematical and statistical methods, the problem of investigating the tangential adhesion between the old and the new concrete in precast-monolithic structures is solved. The influence of various factors, such as water-cement ratio, cement consumption, change in the ratio of the grain composition on the shear resistance is considered. The mathematical and visual dependences of the value of tangential adhesion on the factors under study are obtained. The nature of the destruction of prototypes is described.

The researches have shown that with an increase in cement consumption, the positive effect of the growth of the water-cement ratio on the magnitude of the contact shear strength decreases. The change of the coefficient of grain composition also affects the magnitude of contact strength of concrete for shear. The amount of cement in the concrete mix of a new concrete has the greatest influence on the magnitude of the contact strength of seam of concretes.

Ключові слова: міцність, дотичне зчеплення, бетон, збірномонолітні конструкції, реконструкція.

Keywords: strength, tangential adhesion, concrete, precastmonolithic structures, reconstruction.

Більшість будівель і споруд останнім часом будують із складових бетонних і залізобетонних конструкцій. Це збірні i збірно-монолітні залізобетонні конструкції, комплексні конструкції 3 різних бетонів, монолітні конструкції з незнімною опалубкою, монолітні будівлі при довготривалій перерві у бетонуванні різних частин, добетонуванні при їх підсиленні під час реконструкції або поновленні зруйнованих споруд. Для забезпечення надійності будівель і споруд усі конструкції і контакти між ними повинні мати близький за величиною запас міцності. Тому при проектуванні i виконанні робіт значна увага приділяється конструюванню стиків і їх виконанню в натурі. Крім того, від міцності контактів i монолітності їх стиків залежать експлуатаційні властивості збірномонолітних конструкцій - їх жорсткість, жорсткість і стійкість усієї споруди, тріщиностійкість, ступінь непроникливості стиків. 
Поверхня старого бетону збірної частини збірно-монолітної конструкції, 3 якою необхідно забезпечити зчеплення нового монолітного бетону, це цементний камінь з зернами заповнювача, порами і технологічними (початковими) тріщинами $[1,2]$. Величина зчеплення старого бетону з новим залежить від структури старого бетону i його властивостей. 3 боку нового бетону у процесі зчеплення приймає участь цементне тісто, яке має властивості в'яжучого.

Явища склеювання десятків років вивчалися різними дослідниками. Одна з перших теорій склеювання - механічна. Вона базується на процесі проникнення клею у пори поверхонь, що склеюються. У подальшому рахували, що між клеєм і матеріалом, що склеюють, виникають хімічні реакції, тому значне місце відводилося поверхневим явищам, зокрема, змочуваності.

Міцність контактів бетонів визначається двома факторами: адгезією - міцністю зчеплення клею нового бетону і матеріалу старого бетону, і когезією - міцністю самого клею. Для достатнього контакту необхідно, щоб сили зчеплення поверхні старого бетону і нової бетонної суміші (адгезія) були більше сил зчеплення між частками матеріалу нового бетону (когезія). У випадку недостатньої когезії порушення зчеплення виникає по контактному шару бетонів, а при слабкій когезії матеріалу бетону порушення зчеплення виникає по самому матеріалу. Достатня когезія нового бетону можлива тільки при його затвердінні [3].

Тому була поставлена задача досліджень дотичного зчеплення між старим і новим бетонами у збірно-монолітних конструкціях як одна 3 найбільш вагомих при вивченні резервів зчеплення. Задача вирішувалася з використанням математично-статистичних методів, які отримали широке розповсюдження $[4,5,6]$.

На підставі попередньо проведеного апріорного аналізу інформації достатньо повно враховані усі фактори $\mathrm{X}_{\mathrm{i}}$. Частка 3 них була закріплена на деякому рівні (стабілізована), а друга частка включена в дослідження в якості змінних [7].

Величина міцності шару нового i старого бетонів на зріз характеризує дотичне зчеплення, що виникає у зоні контакту бетонів. У лабораторних зразках-двійках міцність шару на зріз в залежності від складу нового бетону змінювалася від 0,05 до 1,79 МПа. Коефіцієнт варіації у центрі плану складав 16,6\%. Залежність 
величини дотичного зчеплення від факторів варіювання апроксимується поліноміальною моделлю (1) (МПа):

$$
\mathrm{f}_{\mathrm{sh}, \mathrm{j}}=0,884+0,188 \mathrm{X}_{1}+0,203 \mathrm{X}_{2}-0,566 \mathrm{X}_{2}^{2}+0,387 \mathrm{X}_{3}^{2}-0,399 \mathrm{X}_{1} \mathrm{X}_{2} \text {. (1) }
$$

Дисперсія неадекватності отриманої моделі експериментальним даним склала 0,09637, розрахунковий критерій Фішера - 1,683 при вірогідності перевищення $\alpha=0,05$. Максимальне значення міцності дотичного зчеплення $\mathrm{f}_{\mathrm{sh}, \mathrm{j} \max }=1,475$ досягається при $\mathrm{X}_{1}=1,0 ; \mathrm{X}_{2}=-0,173 ; \mathrm{X}_{3}=1,0$, що відповідає натуральним показникам: водоцементному відношенню В/Ц $=0,8$ витратам

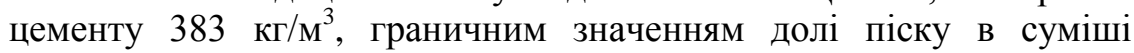
заповнювачів 0,3 чи 0,46 .

Модель залежності міцності дотичного зчеплення в шарі старого і нового бетонів має вигляд полінома другого степеню, включає позитивні лінійні ефекти впливу водоцементного співвідношення i витрат цементу, квадратичні ефекти від варіювання витрат цементу i коефіцієнта співвідношення заповнювачів, від'ємний ефект від взаємодії факторів В/Ц і Ц.

При стабілізації $\mathrm{X}_{3}$ геометричний образ поверхонь відклику представляє собою параболічний циліндр 3 випуклістю до верху (рис.1). Зміна напрямку утворюючої циліндра відображає суттєвий вплив ефекту синергізму факторів, які створюють дану поверхню відклику. Зміна швидкості росту величини міцності дотичного зчеплення в залежності від водоцементного співвідношення складає

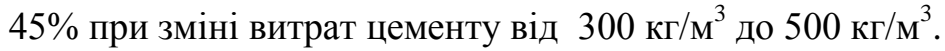

Загальний характер поверхонь вказує на різний вплив зміни водоцементного співвідношення на величину $\mathrm{f}_{\mathrm{sh}, \mathrm{j}}$ в різних областях випробувань.

Для прийнятих малоцементних складів вплив водоцементного співвідношення виражається формулою (2) при $\mathrm{X}_{2}=-1,0, \mathrm{X}_{3}=0$ :

$$
\mathrm{f}_{\mathrm{sh}, \mathrm{j}}=0,116+0,587 \mathrm{X}_{1} \text {. }
$$




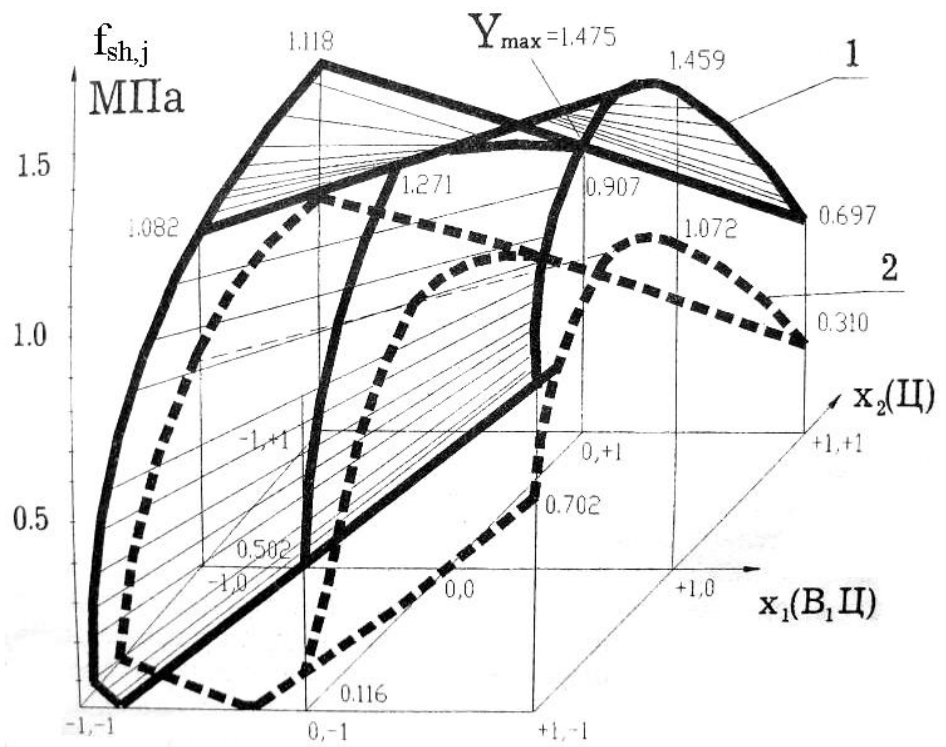

Рис. 1. Залежність міцності шва на зріз від складу нового бетону:

$$
1-\mathrm{X}_{3}=+1 ; 2-\mathrm{X}_{3}=0 \text {. }
$$

Ця залежність відображає позитивний лінійний вплив водоцементного співвідношення. При збільшенні В/Ц тощих бетонних сумішей нового бетону зростає міцність на зріз у контакті його зі старим бетоном. Приріст міцності по абсолютній величині у 1,5 рази перевищує мінімальну. Збільшення міцності на зріз для малоцементних бетонів можна пояснити тим, що підвищення водоцементного співвідношення при рівних умовах приведе до переходу бетонної суміші від жорсткої до рухомої, збільшується іiі легкоукладальність, ущільнюється структура, підвищується проникність маси нового бетону у стару структуру, що сприяє збільшенню адгезії.

У рамках проведених експериментів у тощих бетонних сумішах не виникало суттєвої розшарованості при максимальних водоцементних співвідношеннях, тому від'ємний ефект від збільшення водоцементного співвідношення через неоднорідність суміші не проявився.

Характер руйнування зразків-двійок 3 малоцементними складами відображає меншу міцність нового бетону відносно старого при високій адгезії (в областях максимальних В/Ц). Зразки 
руйнувалися по шву з частковим і повним руйнуванням по новому бетону поблизу шва. При цьому руйнування нового бетону проходило у всіх випадках по цементному каменю, що свідчить про меншу міцність розчинної частини таких бетонів у порівнянні 3 міцністю крупного заповнювача.

Для складів бетону центра плану експерименту залежність міцності шва на зріз від водоцементного співвідношення має вигляд (3) при $X_{2}=0, X_{3}=0$ :

$$
\mathrm{f}_{\mathrm{sh}, \mathrm{j}}=0,884+0,188 \mathrm{X}_{1}
$$

тобто для складів 3 витратами цементу 400 кг/ ${ }^{3}$ і долею піску у суміші заповнювачів $\mathrm{r}=0,38$.

Збільшення водоцементного співвідношення дає відносне збільшення міцності дотичного зчеплення на 53,9\%. В деяких дослідженнях величина $\mathrm{K}=\mathrm{f}_{\mathrm{sh}} / \mathrm{f}_{28}$ бетону різної консистенції показала збільшення відносної міцності зчеплення литих бетонів на $60 \%$ [8].

Таким чином, збільшення рухомості бетонних сумішей 3 середніми прийнятими витратами цементу збільшує міцність контакту бетону на зріз до значень, близьких до максимальних, незалежно від способів досягнення необхідної рухомості бетонної суміші.

Руйнування зразків даної області експерименту проходило по шву з рівномірними виривами старого і нового бетонів, при цьому руйнування проходило з розломом щебеню. Характер руйнування свідчить про однакову участь в опорі зрізаючій силі як старого, так i нового бетону. Висока адгезія у зоні контакту забезпечила їх сумісну роботу, а руйнування по щебеню свідчить про включення в роботу крупного заповнювача, тобто про роботу збірномонолітного стика як єдиного матеріалу.

Вплив варіювання водоцементного співвідношення на величину міцності дотичного зчеплення для області високоцементних бетонів має вигляд (4) при $\mathrm{X}_{2}=1, \mathrm{X}_{3}=0$ :

$$
\mathrm{f}_{\mathrm{sh}, \mathrm{j}}=0,521-0,210 \mathrm{X}_{1}
$$

для складів із витратами цементу 500 кг/ $\mathrm{m}^{3}$ і долею піску у суміші заповнювачів $\mathrm{r}=0,38$. Лінійна залежність для таких складів внаслідок впливу синергізму факторів В/Ц і Ц змінює знак.

Для бетонів 3 великими витратами цементу збільшення водоцементного співвідношення приводить до зниження міцності шва на зріз. На доцільність збільшення водоцементного 
співвідношення до деякої межі наголошували і інші автори [9]. Відомо, що підвищення водоцементного співвідношення більше оптимального для даних складів бетонів призведе до збільшення усадочних деформацій, особливо в перший період тужавіння.

Для високоцементних рухомих і литих сумішей 3 високим водоцементним співвідношенням у процесі тужавіння цементного каменю утворюється рихла пориста структура, на міцність якої менше впливає крупний заповнювач. У той же час, величина сил когезії таких тужавіючих бетонах перевищує сили когезії (рис.2) i, як слідство цих процесів, спостерігається послаблення контактної міцності на зріз більш, ніж у 1,6 рази.

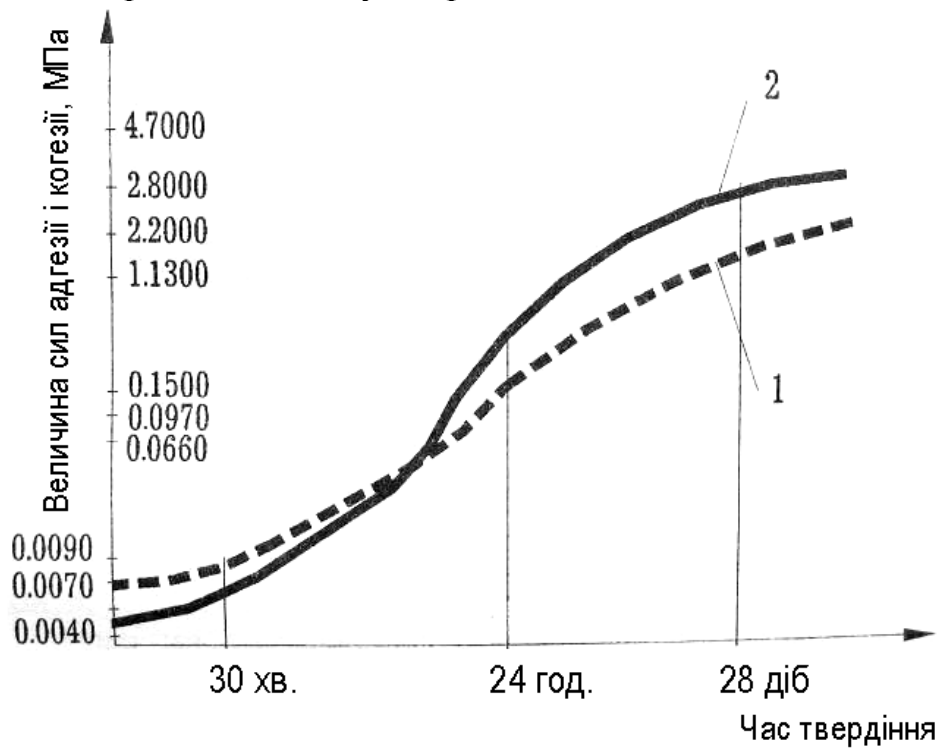

Рис. 2. Залежність величини когезії і адгезії портландцементу від часу твердіння: 1 - залежність адгезії від часу тужавіння; 2 - те ж, когезії.

Зміна впливу водоцементного співвідношення на міцність контактів бетонів на зріз свідчить про те, що при зрізі міцність шва забезпечується не тільки адгезійними силами як при осьовому розтягу, а й міцністю самого матеріалу бетону. Це можна пояснити тим, що в опорі зрізу приймає участь, у більшій мірі, механічне зчеплення у зоні контакту бетонів. При проникненні у нерівності і пори маси речовини нового бетону в процесі тужавіння 
утворюються шпонки. Від їх міцності в певній мірі залежить величина механічного зчеплення. У той же час при значному перевищенні міцності нового бетону виникаючі у ньому когезійні сили перевищують величину сил адгезії, руйнуючи зв'язки, що встановилися у початковий момент омонолічування.

Результати досліджень показали, що найбільшу міцність зчеплення на зріз мають зразки з литого бетону, що співпадає 3 залежністю "2" (рис.3), що відображає вплив зміни водоцементного співвідношення на нульовому рівні по $\mathrm{X}_{2}$ (витрати цементу).

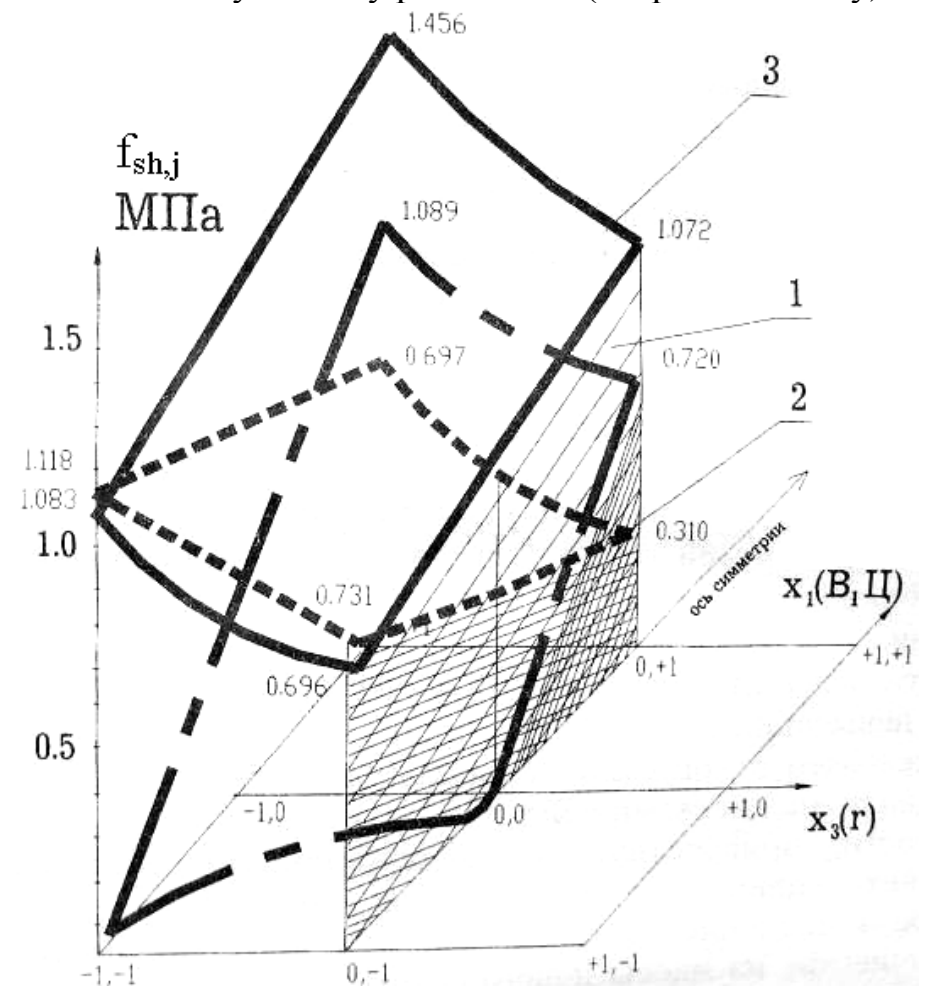

Рис. 3. Зміна впливу $\mathrm{r}$ від В/Ц залежно від витрат цементу:

$$
\begin{gathered}
1-\text { при Ц }=300 \text { кг } / \mathrm{M}^{3} ; 2-\text { при Ц }=400 \kappa г / \mathrm{M}^{3} ; \\
3-\text { при Ц }=500 \kappa \Gamma / \mathrm{M}^{3} .
\end{gathered}
$$

Вплив витрат цементу на величину міцності шва на зріз у зоні контакту старого і нового бетонів підпорядковується загальній квадратичний залежності. Для сумішей 3 мінімально прийнятим водоцементним співвідношенням міцність шва збільшується по квадратичній залежності і досягає максимального значення при 
максимальних витрат цементу. Це можна пояснити тим, що при постійно низькому водоцементному співвідношенні зі збільшенням кількості цементу збільшується жорсткість бетонної суміші, надлишок цементного тіста становиться тією клеючою масою, яка забезпечує достатньо високу адгезію, а міцність нового бетону визначає міцність мікрошпонок при механічному зачепленні в контакті бетонів. При мінімальній 3 прийнятих величин водоцементного співвідношення в найменшій мірі проявляються деформації усадки нового бетону, тому міцність контакту бетонів на зріз досягає досить високих значень, більше $75 \%$ від максимального.

Руйнування зразків, склади яких відповідали максимальним витратам цементу при мінімальному водоцементному співвідношенні, проходило по шву з виривами старого бетону. Це свідчить про перевищення міцності нового бетону над міцністю старого при достатньо високій міцності контакту нового і старого бетонів на зріз.

При постійному водоцементному співвідношенні міцність дотичного зчеплення при збільшенні витрат цементу від $300 \mathrm{\kappa г} / \mathrm{m}^{3}$ до 400 кг $/ \mathrm{M}^{3}$ збільшується більш, ніж в 2,5 рази, однак, при подальшому збільшенні кількості цементу починає впливати наявність усадочних деформацій і міцність шва на зріз зменшується на $30 \%$ від максимального значення для цього водоцементного співвідношення. Подібні результати досліджень отримали і інші вчені $[9,10]$.

Як випливає з рис.3, область мінімальних значень залежності міцності шва на зріз від варіювання крупного і мілкого заповнювачів та водоцементного співвідношення при різних витратах цементу полягає на основному рівні варіювання $r$. Очікувано, що такий характер залежності міцності шва на зріз від частини піску пов'язаний з розподілом ролей крупного и мілкого заповнювачів якісно змінює вплив коефіцієнта співвідношення заповнювачів.

\section{Висновки}

1. Зі збільшенням витрат цементу позитивний вплив росту водоцементного співвідношення на величину контактної міцності на зріз зменшується, а при витратах цементу 500 кг $/ \mathrm{M}^{3}$ контактна міцність бетонів на зріз знижується у 1,6...2,4 рази зі збільшенням 
В/Ц з 0,48 до 0,80. Підвищення контактної міцності старого і нового бетонів на зріз при збільшенні витрат цементу нового бетону спостерігається при набетонуванні жорстких i малорухомих бетонних сумішей.

2. Зміна коефіцієнта зернового складу впливає на величину контактної міцності бетонів на зріз. Зміна $\mathrm{r}$ від середніх до максимальних і мінімальних значень збільшує контактну міцність бетонів на зріз у 1,5...2,2 рази. Найбільший вплив на величину контактної міцності бетонів шва на зріз здійснює кількість цементу в бетонній суміші нового бетону.

\section{Список використаних джерел}

1. Лыков А.В. Явление переноса в капиллярно-пористых телах. ГИТТЛ. - Москва, 1954. - 296 с. 2. Дорофеев В.С. Технологическая поврежденность строительных материалов и конструкций / В.С.Дорофеев, В.Н.Выровой. Монография. - Одесса: Город мастеров, 1998. - 168 с. 3. Адсорбция в микропорах. Под ред. Дубинина В.В. - АН СССР, ин-т физ. химии: Наука, 1973. - 216 с. 4. Адлер Ю.П. Планирование эксперимента при поиске оптимальных условий / Ю.П.Адлер, Е.В.Макарова, Ю.В.Грановский. - Москва: изд-во "Наука", 1976. - 279 с. 5. Вознесенский B.А. Статистические методы планирования эксперимента в техникоэкономических исследованиях М.: Финансы и статистика, 1981. - 263 с. 6. Balek V., Dahnalek I. Cem. And Cong. Res. 13. - №1, 1983. - P.1-6. 7. Дорофеев В.С. Прочность контактов сборно-монолитных конструкций / В.С.Дорофеев, Н.В.Пушкарь // Сб. научных трудов: «Актуальные научные исследования в современном мире» - Переяслав-Хмельницкий, 2019. Вып. 3 (47), ч. 1. - C.118-127. 8. Hager K. Versuche zur Feststellung der Scherfestigkeit und der Wasserdichtigkeit des Betons in den Arbeitstugtn bei Verschidener Fugenbehandlung / K.Hager, E.Nenning // Deutscher Ausschuss für Eisenbeton. - Н.69, 1932. 9. Урьев Н.Б. Коллоидные цементные растворы / Н.Б.Урьев, М.С.Дубинин. - Л.: Стройиздат, 1980. - 192 с. 10. Матьязов С.М. Опыт исследования свойств контактной зоны в бетоне // Сб.науч. трудов: "Расчет и проектирование строительных конструкций с применением ЭВМ" - Ташкент: Ташк. политех. ин-т, 1987. - С.64-67. 